\title{
Theorising pornogrammar in the Akan folktale tradition: The trickster's rhetorical indirection and sexual indiscretion
}

\author{
J.B. Amissah-Arthur \\ Lecturer \\ Department of English \\ University of Ghana, Legon, Ghana \\ Email: jbamissah-arthur@ug.edu.gh
}

Submitted: April 16, 2018 / Accepted: February 25, 2019 / Published: October 4, 2019

\begin{abstract}
In the oral and written folktale tradition of the Akan people of Ghana, Kweku Ananse is the archetypal trickster. Simultaneously, he is divinity and mortal, anthropomorphic and zoomorphic, mind and matter, culture hero and comical villain. Though the phenomenon of Ananse has been widely studied, the question of Ananse's sexually-oriented verbal traps has received very little or no attention. The present essay attempts to contribute towards filling this gap by raising fundamental questions about Ananse's language. What linguistic stratagem informs the apparent ease with which he appropriates other people's wives? We find that as the quintessential linguist, Ananse's mastery of rhetorical indirection is fundamental to his success as a libertine. The essay examines the forms of rhetorical indirection and linguistic stratagem by which Ananse negotiates sex, whether he is taking advantage of a friend's wife, seducing the king's daughter or appropriating Nana Nyakopon the Supreme God's spouse.
\end{abstract}

Keywords: Akan, Ananse, phallus, pornogrammar, trickster

\section{Introduction}

Ananse, the archetypal trickster of the Akan folktale tradition, has been long documented as the quintessential linguist. The centrality of language to Ananse's role as trickster has roots in Akan cosmology. The Akan proverb, Ananse annton kasa - Spider did not sell language (Yankah 1991,p.47) attests to the aboriginal Akan belief that Ananse owned language, and gave it freely to humankind as a cultural gift. Ananse's ownership of language is 
reinforced by three tales in the Anansesem (Ananse tale) tradition: 'How It Came about that the Sky-God's Stories Came to be Known as "SpiderStories"' (Rattray, 1930, p. 55), "How It Came about that Men Commit Evil by Night' (p. 72) and 'How Toothache and Birds Came into the Tribe' (p. 178). In the first of the three tales, Ananse acquires Nyankonsem (God's tales) from Nyankopon (God) by performing the seemingly impossible tasks of capturing very dangerous animals including, the python, hornets and fairies, and presenting them to God. After acquiring the tales, Ananse names them after himself as Anansesem, and shares them with humankind. The second tale is a version of the earlier one. In the present tale, God is unable to decide which of his three sons - Night, Moon and Sun - he should enthrone as king over the universe. Ananse manages to convince God to choose Sun, the youngest child, over the older children. As a reward for his good counsel, God gives Ananse his (God's) tales which the trickster shares with humankind. In the third tale, a mysterious bird strips the people of their jaws so that nobody is able to speak. The bird comes every day, at noon, to gloat about his success in rendering the people dumb. Ananse uses his wits to trick and kill the bird, and give back to the people their lost jaws. A common thread binds all the three tales cited: Ananse's ability to recover language in the form of story and speech, and giving it freely to humanity. It is important to stress that story, in the Akan tradition, is closely linked with speech. In fact, the former implies the latter in the Akan context, since the Akan storytelling tradition is a vibrant performance tradition involving, speech, music, dance and drama. All the tales cited above provide a legitimate basis for the Akan belief that Ananse owns language. The tales represent, however, a few of the many instances of Ananse's boundless culture heroism. In other instances: he furnishes humanity with wisdom when he shatters the pot containing the resource (Rattray, p. 4); he spreads agricultural technology by making the hoe available to humankind (p. 42); he struggles with God over women, and in the process spreads diseases such as syphilis and gonorrhoea (p. 76); he establishes the Akan ethical practice regarding the sanctity of secrets and personal confidences (p. 129). Indeed, it is Ananse who brings the Akan society into existence. To buttress our argument regarding the centrality of Ananse to Akan cosmology, we cite below a sacred Akan myth of origin (Odomankomasem), which is also an ancient Akan drum text: 
Henako se ${ }^{1}$,

Henako se,

Henako se,

Hena na oko se 'Te,

Ma 'Teko se Ananse,

Ma Ananse ko see Odomankoma,

Ma Odomankoma

Boo Adee?

Who gave word,

Who gave word,

Who gave word?

Who gave word to Hearing,

For Hearing to have told Ananse,

For Ananse to have told Odomankoma,

For Odomankoma

To have made the Thing [or the world]?

From the text above, Ananse's role in the creation of the world is clarified. Two points are important here: first, it is Ananse who hears from $\mathrm{Te}$ ('Te' understood as a demiurge); and second, it is Ananse who tells Odomankoma (the creative energy of God) to create the world. 'Te' or 'Hearing' suggests the act of being spoken to, and, therefore, implies language. In the myth, Te/Hearing/Language first speaks to Ananse, indicating that Ananse is the first recipient of primordial speech. Second, it is Ananse who utilises the latent agency of language to get the world created: he tells God what to create, canonising Ananse as master of both language and creation, a bona fide Akan culture hero. As owner of language Ananse expertly manipulates language to serve his purpose. He constantly resorts to linguistic indirection - puns, ambiguities, tropes and rhetorical gimmicks, including incantations, nsabran (appellations) and songs as strategic tools to execute his tricks. Often, he overcomes his victims by means of verbal traps. Yankah (1995) draws our attention to the importance of indirection in Akan rhetoric. He suggests that to the Akan, 'the perceived power of the spoken word...calls for the deployment of various strategies of speaking that may obviate crises. These include avoidance or discretionary use of verbal taboos, apologizing for their use, using euphemisms, or resorting to indirection' (p. 51). In the view of Claudia V. Camp (2000), 'Ananse...presides over and authorizes a tradition that is

'J.B. Danquah, The Akan Doctrine of God, ([1944], 1968). 
terribly concerned with language and its proper use' (p. 81). The fact is that Ananse knows all the rhetorical protocols of the Akan, and applies them so cleverly that he escapes censure even when he is undermining social norms. We can postulate, then, that Ananse practises 'verbal hygiene' (Cameron 1995/2012). The 'term [verbal hygiene] is intended to encompass a diverse set of activities linked by the idea that some ways of using language are functionally, aesthetically, or morally preferable to others' (Cameron, 1994, p. 383). In the present essay, we intend to discuss Ananse's language in the context of a specific body of folktales that have curiously evaded critical interest: the erotic Ananse tale. In providing the analysis, we are aware of the distinguished scholarship on the West African trickster done by, for instance, Alan Dundes (1971), Lee Haring (1972), Robert Pelton (1980), Kwesi Yankah (1983/1989/1999), Kwadwo Opoku-Agyemang (1995) and Naana J. Opoku-Agyemang (1999). While Dundes and Haring study the structural paradigms of the trickster tales, Pelton discusses the trickster's role as a mythical figure. He also delves into the trickster's sexuality and language. Yankah concerns himself variously with questions regarding the origin, sacrality and ethics of the trickster. Kwadwo Opoku-Agyeman projects Ananse as the paradigm of behaviour that enables the enslaved African to outwit and escape enslavement, while Naana Opoku-Agyemang outlines the gender-role perspectives involved in the social structure and narrating practices of Ananse tales. With the exception of Pelton's, none of the studies reviewed takes as its burden the subject of Ananse's sexuality and language. Pelton's study does not link Ananse's sexuality with his language, however. It merely discusses the two topics as disparate subjects. In view of the identified gap in the scholarship, the present essay examines the impact of Ananse's sexuality on his language; precisely, the study analyses how Ananse's linguistic craftiness enables him to succeed as a libertine. The essay shall also attempt to theorise the cultural function of the Akan trickster's phallocentricity.

\section{Theoretical framework}

In providing the analysis, we intend to apply Roland Barthes's (1971) theory, pornogrammar, which derives from his study of the erotic novels of Donatien Alphonse Francois (Marquis de Sade), an eighteenth century French philosopher and writer. Sade's works are saturated with illicit sexuality, torture, pain, debauchery and orgiastic pleasure, leading to words 
such as 'sadism', 'sadistic' and 'sadomasochism' being derived from his name. In developing his theory of Sade, Barthes delineates reduplicative patterns of criminal sexuality in Sadian novels such as: Justine, or the Misfortune of Virtue (1791); Juliette (1787-1801); and The 120 Days of Sodom, or the School of Libertinage (1785, [1904]). Barthes argues that there exists a pornogrammar when, first, recurring acts of eroticism can be subjected to a discursive, oratorical rendition; and, second, when those acts can be delineated and combined, in the manner of linguistics, to form the social structure of the story.

For...there is no eroticism unless the crime [sexual passions, debauchery, illicit liaisons, sadism] is "reasoned"; [and] to reason means to philosophize, to dissertate, to harangue, in short, to subject crime [understood as sexual crime] to a system of articulated language, but it also means to combine according to precise rules the specific action of vice, so as to make from these series and groups of actions a new "language," no longer spoken but acted; a "language" of...love (Barthes, 1989, p. 27)

From the above, there are two levels of pornogrammar: first, the verbal, rhetorical level, which is the discursive, naturally-linguistic level; and, second, the level of action, which derives from the linguistic principle of contiguity, and, therefore, represents a pseudo-grammatical structure. In other words, the second level of pornogrammar is a metonymic representation of language, an artificial language based on the simulacrum of linguistic combination. In sum, pornogrammar represents 'a grammar of the erotic - with its erotemes and rules of combination' (Barthes, p. 165) producing a language upon language. Critical responses to Barthes' theory have been varied. Philippe Roger, restating Barthes himself, conceptualizes pornogrammar as language turned on itself in a sort of harmless linguistic game whose effect is felt by language itself. In his view, though the monstrosity and criminality which represent the basis of pornogrammar seems, at first, to be directed at a referent, it soon becomes clear 'that the real victim is language' (qtd in Frappier-Manzur, 1996, p.95). Lucienne Frappier-Manzur rejects Roger's stance, and insists that the works of Sade, and therefore, pornogrammar, represents "actualization of desire" (Frappier-Manzur, p. 93); in other words, pornogrammar encourages people to practise their base fantasies and desires, a charge which Barthes denies. According to Frappier-Manzur, the theory captures 'the programmatic discourse of the orgy between phantasy and its execution' and 'assimilate[s] the question of the gap between desire and its realization’ (p. 94). In rejecting views such 
as Frappier-Manzur's, Barthes reiterates the linguistic position, and insists that the theory turns 'the impossibilities of the referent...into possibilities of discourse, it is on the level of meaning, not of the referent, that we should read [it]' (p. 95). In this sense, pornogrammar becomes a playful linguistic paradigm whose focus rests purely on the creative use to which an author or character uses sexual innuendos. In borrowing Barthes' theory for the study of the erotic Ananse tale, we recognize the limitation involved in submitting a traditional African folk-genre and its hero to an European intellectual, theoretical paradigm. This shortcoming is minimised, however, if we realise that both Ananse and the prototypical Sadian libertine have much in common, and, in fact, do reflect each other in many fundamental respects. But they do deflect from each other also in other aspects of character. For instance, unlike Ananse, the sexuality, bestiality and criminality of the Sadian libertine are decidedly exaggerated and exponentially perverted beyond the limits of human sanity. In spite of the divergences, there are clear points of convergence, such as: sex, food, site of action, population, money and language. For example, Sadian debauchery reflects Ananse's lecherousness and desire for illicit sex. The Sadian boast about virility and phallic size (Barthes, 1989, p. 18) mimics Ananse's claims about his phallus. Sadian food which represents the fulcrum of all social and libertine interactions in the Sadian novel (p. 18) parallels Ananse's food, which is the central theme of almost all Ananse tales; and just as Sadian food is variously utilised as a bait and poison for the libertine's victim, Ananse's food works similarly in the sexual arena as a bait and poison for his victims and rivals. In terms of site of action, Sadian site is remarkably identical to Ananse's: both sites are 'hermetically isolated from the world' so that 'one travels only to shut oneself away' in an otherworldly, liminal environment (p. 15). As regards population, Sadian society is stratified, but such social classifications become blurred in the context of libertinage, where master becomes victim, and victim master (p. 30). Similarly, Ananse does not discriminate in his choice of libidinal interest: he takes advantage of his friends' wives, impregnates married women in their own matrimonial beds, tricks the village chief for his daughter, marries all the women in one village, and even travels to the cosmic realms to seduce Nyankopon's (God's) wife. Ananse disregards all social distinctions when sexuality is concerned, just as his Sadian counterpart does. Sadian money is not merely used to acquire sex, it is also a sign of social class (p. 23). Ananse, on the other hand, is not wealthy at all; indeed, Ananse is a poverty-stricken character. In spite of his 
very weak financial status, he schemes to get 'property' to further his libertine life. For instance, he tricks Nyankopon for his goat which he uses as a bait to lure his victims, claiming he is God's servant. Being God's messenger obviously suggests social and divine pedigree. At another time, he manages to acquire honey, and provides the delicacy as a symbol to claim divine status, since honey is traditionally seen as food for the gods. Using his "status," he seduces and elopes with the king's daughter. Lastly, the Sadian protagonist and Ananse are both eloquent, and demonstrate mastery of language. Indeed, both pornogrammar and the Anansesem (Ananse tale) genre are highly linguistic phenomena. The wide-range of convergences between the Sadian protagonist and Ananse discussed above justifies our use of Barthes' theory as the appropriate framework for analysis in the present study. In using Barthes' framework, our focus is not on the action of the trickster in itself. We do not intend to interrogate the social structure of the story, or how the units of sexual action have been combined to form a superordinate structure of sexuality. Our focus is on the first level of pornogrammar, the naturally-linguistic, rhetorical basis of the tale - what Barthes calls the libertine's 'dissertation, 'philosophizing' or 'harangue' (1989, p.27). Barthes emphasises that: "The dissertation "seduces," "animates," "misleads," "electrifies," [and] "inflames"; .... [D] uring the dissertation, erotic energy is renewed' (p. 146). It is this seductive, inflammatory and, ultimately, misleading character of language we intend to examine in the present study. It is our considered view, however, that Sadian discourse - the 'dissertation' - is not as misleading as Barthes claims, and that it represents a rather graphic speech. We decline to cite a direct example of Sadian discourse because of its impropriety in the present context ${ }^{2}$. Ananse's language, on the other hand, represents a more polished, nuanced and 'verbally hygienic' (Cameron. 1994, p. 383) discourse aimed at achieving the same libidinal effect as Sadian language. Ananse uses language that is decidedly deceptive and ludicrous; and taking advantage of the protean nature of language, he sets sexual traps to lure the desirable women in his world. Accordingly, we extend the definition of 'pornogrammar' to include Ananse's subtle art of seduction. We conceptualise pornogrammar, therefore, as: a rhetoric of the erotic based on linguistic indirection and aimed at procuring the pudenda through illicit means without attracting censure.

${ }^{2}$ For an example of Sadian language, see Marquis de Sade, The 120 Days of Sodom ([1785], 2002), trans. Richard Seaver and Austryn Wainhouse, https://supervert.com/elibrary/marquis-de-sade/ 


\section{Data and Justification}

We shall examine a select set of oral and written tales for the analysis. The former set of tales shall be taken from the present writer's own repertoire of Akan tales as well as R.S. Rattray's Akan-Ashanti Folktales (1930). As an indigenous Fanti-Akan, the present writer has been involved in the performance of Ananse tales since childhood, and, therefore, boasts not merely a specialist knowledge of the tradition, but also a comprehensive repertoire of the tales. His instinctive understanding of the dynamics of form and nuances of language of the tradition justifies the selection of tales from his collection. R.S. Rattray's Akan-Ashanti Folktale, on the other hand, represents, perhaps, the first scientific collection and study of the Akan folktale. Rattray lived among the Asante people of Ghana for eight years from 1920 to 1928 - as the colonial government's first official anthropologist in Asante. Prior to the appointment, he had lived in Ghana intermittently since 1906. He had a good command of the Twi language, and collected the tales from 'uneducated' Akan people whose use of language reflected the aboriginal, precolonial Akan linguistic situation (Rattray, 1930). His AkanAshanti Folktales, therefore, represents the most authentic ethnographic collection of Akan tales. The two sources of oral tales discussed above provide a rich lode of social, cultural and linguistic material which will form the basis of analysis of the present paper. The latter set of tales - the written tales - shall include Efua Sutherland's The Marriage of Anansewa (1975) and Yaw Asare's Ananse in the Land of Idiots (2006). Since Sutherland and Asare appropriate the oral folktale tradition for the purpose of literary writing, their works provide a comparative body of texts which enables us to examine the divergences and convergences that occur between the oral and written folktale traditions.

\section{Ananse's sexuality and indirection in the oral folktales}

We begin our analysis by first providing brief summaries of the tales being examined. We start with the tale, "We Are All Ananse's Children," a tale told to the present writer by his octogenarian father in 2017. In the tale:

Nyankopon (God) sanctions a match of atentam - a traditional form of wrestling - between Ananse and Pataku (Wolf) to determine who wins the hand of Araba Ansaba, the most beautiful woman in the world. She is said to be so tall and huge that her breasts nearly touch the ground when she walks. Ananse is so captivated by Araba's phenomenal torso that he fantasises about her the entire day. All night, he plays on his flute serenading Araba's 
breasts and pudenda. On the day of the wrestling match, Ananse hides many pots of water and gongs in a thicket near the venue of the fight. Just when the fight is about to start, Ananse excuses himself, and goes into the thicket to prepare. He spills the water in the pots so that there is a deluge comparable to Bosompo (the Sea deity ${ }^{3}$ ). When Mawere (Turkey), the gobetween, asks Ananse what is causing the flood, Ananse responds: 'Mere gunsu' - ['I am urinating.'] On hearing this, Pataku, Ananse's opponent, becomes very frightened and disturbed. He thinks that if his opponent's urine can cause such a devastating flood, then he (Pataku) stands no chance in the impending fight. After a long period of 'urinating', the entire place is so flooded that there is hardly any dry land left for the fight. Then, suddenly, Ananse starts beating the hidden gongs, and making a lot of cacophonous noise. When Mawere enquires about the ringing, Ananse replies, 'Me benyin rebo ne dewur' - ['my manhood is ringing its bells.'] He implies that the swinging of his phallus against his gonads produces the deafening sounds. At this point, Pataku concludes that, if Ananse's phallus is so huge as to cause a flood, and so tough as to produce such an awful noise, then Ananse must be a gigantic and invincible warrior. Pataku decides he cannot fight Ananse; he flees from the battlefield. Ananse, therefore, wins Araba's hand in marriage without throwing a punch. Ananse impregnates Araba every night when she comes to sleepover. In the morning, when Araba is going to her own house, which is located at the end of the world, she will give birth on the way. The next night, she will get pregnant again by Ananse, and will give birth the following day at a different location on her way home. Through this repeated procreative act, Ananse and Araba populate the whole world with children. That is why the elders say we are all Ananse's children irrespective of where we live in the world.

The following tale, "Why it is the Elders Say we should not Repeat Sleeping-Mat Confidences," taken from Rattray's collection, is another version of "We Are All Ananse's Children." In the tale:

Nyankopon (God) makes a vegetable farm. He plants okras, onions, beans, garden-eggs, peppers and pumpkins. Unfortunately, weeds and nettles grow in the farm choking the vegetables. Nyankopon throws a challenge to the effect that any man who successfully clears the farm without scratching himself will be given Abena Nkroma, Nyankopon's daughter, as wife. All the men who try to weed the farm fail in the attempt because the nettles cause them to itch so badly that they scratch themselves. Ananse accepts the challenge to weed the farm. When a passer-by asks why he is weeding a farm that nobody has been able to weed, he says it is for the love of a beautiful girl whose arm is like this. He will pretend to show how slender the girl's hand is, but will use the opportunity to scratch his own itching arm. When another passer-by enquires why he is burdening himself with the impossible task, he will say it is for the sake of a beautiful girl whose thigh is like this. He will, again, use the opportunity to scratch his own itching

3The coastal Akan regard the sea as a god called Bosompo or Nana Bosompo. 
thighs. This way, Ananse manages to clear the farm 'without' scratching himself. He is then given the hand of Abena Nkroma in marriage. (Rattray, 1930, pp. 129-133)

"How Ananse Got Aso in Marriage," our final oral tale under consideration, is also a modified version of the earlier two tales. In the tale:

Akwasi Ninkunfuo is unable to impregnate his wife, Aso. Unhappy with the situation, Nyankopon (God) challenges the young men in the town to woo Aso, but on the condition that whoever succeeds in impregnating her marry her. Kweku Ananse joins the contest. He visits the couple with a gift of meat, and asks for lodging for the night. He claims: "It's the Sky-god who is sending me, I am weary, and I am coming to sleep here" (135). He asks Aso to cook for him. As she prepares the meal, he asks if she is cooking fufuo or eto. When she says it is fufuo, he says: "Then it is too little; go and fetch $a$ big pot [and] [c]ome get meat. [...] [I]f you had a pot big enough, I would give you enough meat..." (135). He then gives Aso forty hind-quarters of great beasts. During the meal, Ananse poisons the food with a purgative, and quits eating. Not knowing what Ananse has done, Akwasi eats the rest of the food. Before the couple retire to bed for the night, they enquire from Ananse what his name is. Ananse says he is called Sore-ko-di-Aso (Riseup-and-make-love-to-Aso). When the couple sleeps at night, Ananse locks them in from the outside. In the middle of the night Akwasi develops a stomach ache because of the purgative Ananse puts in his food. Akwasi tries to go to the washroom, but he is unable to open the bedroom door. Ananse has locked it from the outside. Desperate, Akwasi calls Sore-ko-di-Aso (Rise-up-and-make-love-to-Aso) to open the door. Ananse immediately opens the door. While Akwasi is away, Ananse goes to Aso to demand sex. He asks: "Did you hear what your husband said? He said I must rise up and make love to you" (137). Aso cannot deny what her husband said, so Ananse appropriates her. In the course of the night, Akwasi calls Sore-ko-di-Aso nine times. On each occasion, Ananse goes into Aso's bed to take advantage of her. He impregnates her in the process. When Akwasi finds out about the pregnancy, he divorces her. Ananse then marries her. That is how Ananse got Aso in marriage. (Rattray, 1930, pp. 133-137)

The next segment of tales we shall consider are the written folktales. These are literary works based on the Akan oral folktale tradition, and therefore, demonstrate simultaneous convergence with and divergence from the oral tradition, demonstrating the dynamism of Anansesem as a cultural and literary tradition. The first tale in this category of texts is Efua Sutherland's The Marriage of Anansewa. In the drama, Ananse promises his daughter, Anansewa, in marriage to four chiefs: Chief of Sapa, Togbe $\mathrm{Klu}$ IV, Chief of the Mines and Chief-Who-Is-Chief. Ostensibly, he generates a tense libidinal competition around Anansewa for economic expediency. He intends to give the girl to the one who pays the highest dowry and 
demonstrates largess. In order to extricate himself and his daughter from the potentially dangerous and embarrassing nuptial entanglements, Ananse employs nsabran - Akan praise poetry- as rhetorical indirection. In the Akan tradition, nsabran or appellation is a verbal art-form performed for chiefs by court-poets. The artistry of the poet is judged by his or her ability to recite the heroic achievements of the chief and his predecessors, or to coin high-sounding ancestral names, titles and honorifics in praise of the chief. The performance of appellations, therefore, provides Ananse with the platform to demonstrate his only known strengths: verbal artistry and guile. We provide below the relevant sections of Ananse's appellation for each of the four chiefs. The following extract represents a section of the appellation for the Chief of Sapa:

Oh! Mighty-Tree-Of-Ancient-Origin!/Mighty-Tree-Of-Ancient-Origin,/ Rooted in the shrine of deity. (Act 1)

The appellation for Togbe Klu includes the following lines:

Prickly-pear/Cactus.../Thanks to your prickles/The enemy bleeds/Thanks to your capacious leaves/Those you love will always find within them/ Water to refresh them. (Act 1)

For Chief of the Mines, Ananse produces the following appellation:

You are coming again/Aren't you?/You are coming?/Oh where shall we sit?/Whendriver ants/Are astir/All over our ground? (Act 1)

The last appellation meant for Chief-Who-Is-Chief goes as follows:

Oh! Fire-extinguisher!/Fire-extinguisher/You have caused flame flashes to darken. Blazing-Column-Of-Fire-Who-Says-I-Will-Not-Be-Halted/Has come to a full stop. Masculine-One-Destined-To-Contend-To-Victory!/You consume fire. (Act 1)

Yaw Asare's Ananse in the Land of Idiots provides the last written tale for the study. In the drama, Ananse, again, employs a remarkable range of verbal resources in his attempt to outwit another royalty, Dosey, King of Dim-Nyim-Lira. We provide the bare outline of the plot below:

Ananse desecrates the puberty rites of the maidens of Dim-Nyim-Lira. He is supposed to die for his action, but pleads for his life by offering to weave a Kente cloth for Sodziisa, the king's daughter. To facilitate his work, he asks Sodziisa and her female friends to come to his craft shop and sing. When he hears the women approaching, he says: "O come, pretty...maidens, come! Come sing and dance, so the melodies of your voices and the contours of your bodies will smoothen the passage of my needle as I weave." $\left(2^{\text {nd }}\right.$ Movement, my emphasis) 
In all the tales cited above, Ananse consistently employs rhetorical indirection or kasakoa (Yankah, 1991, p. 52) to veil his sexual intentions. "We Are All Ananse's Children," for instance, represents a highly mythical aetiological tale that provides the Akan view on creation. The complexity of the tale finds reflection in the complicated rhetoric employed by the trickster. To start with, Ananse turns an ordinary battleground into a complex and tricky linguistic space where rhetorical gimmicks operate. He redirects the discourse from the combat context to the genital arena, from the martial to the marital, and from fisticuffs to fecundity. What is originally a straightforward wrestling match is rhetorically transformed into a phallic contest. In this transformed space, Pataku's muscular stature is rendered redundant since virility, and not brute physique, becomes the yardstick. Ananse is clearly the stronger man here because he boasts a phenomenal phallus. For instance, his urine provides so much liquid that it turns into a sea-like deluge; also, the swinging of his phallus and gonads makes a deafening cacophony. By projecting ithyphallus, Ananse rejects the traditional Akan martial criterion by which a woman may select a useful husband. For Ananse, the ability to procreate rather than to provide sustenance for one's family should be the benchmark for selecting a good husband. By shifting the context from the martial to the marital through subtle linguistic indirection, Ananse demonstrates his mastery of language. Again, by redirecting the discourse from the original fight context to the phallic context, Ananse pursues a rhetorical style that is lost on everyone but Pataku, the intended recipient of the discourse. Nobody present at the fight venue seems to understand Ananse's nonsensical pranks. Mawere, the referee, keeps asking Ananse to tell him what is going on. In our view, Mawere does not realise that he is in a highly sophisticated linguistic context, and that Ananse's supposed nonsensical joke is actually a coded message targeted at Pataku, his opponent. By brandishing a huge phallus, Ananse does not merely draw attention to Pataku's standard phallus, he conspicuously inscribes his own superior masculinity. Ananse's euphemistic expression - 'me benyin rebo ne dewur,' - ['my manhood is ringing its bells'] - produces a metaphoric meaning that elicits a phobic reaction from Pataku. The supposed phallus makes noise, and it is heard far and near. The fact of the size of Ananse's supposed member is figuratively established for Pataku, his opponent.

The discourse and its implication produces the psychological phenomenon of phallophobia in Pataku. Phallophobia is defined as fear of 
the phallus, especially the erect phallus (Subba, 2014, p. 346). Pataku's phobia and flight from the battlefield can be explained in Freudian and Fanonian terms. According to the former, "phobias do not occur at all when the vita sexualis [or the sexual energy] is normal' (Freud, 2004, p. 102). Evidently, Ananse's demonstration of sheer phallic power reduces Pataku's vita sexualis. In other words, Ananse induces phallic diminution (Fanon, 1967, p. 159) or psychological castration of Pataku by a mere linguistic trick.Viewed from another perspective, Ananse's rhetoric produces a feminising effect on his opponent. If 'phallophobia is a neurotic symptom shared by all women' in patriarchal societies (Wang, 1990, p. 56), then it follows that Pataku's flight from Ananse's phallus represents feminisation. Pataku's feminisation involves a psychological dwindling of his phallus until it has transmuted into the pudendic phallus: the clitoris, making him 'female'. In this sense, the flight of the feminised Pataku from Ananse's phallus represents an inversion: a simultaneous repulsion of and desire for the phallus. Fanon describes the act as the trick of the feminine sexual ego to defend itself (1967, p. 156). In the context, Ananse's phallus becomes repulsive to Pataku because it threatens his/her transmutative pudenda, yet (s)he desires the self-same phallus because it provides empowerment. In this sense, phallophobia signifies as a sadomasochistic phenomenon in Pataku's split consciousness: his male self wants to appropriate the organ while his female alter-ego rejects it.

From the analysis above, it is evident that by a seemingly simple and irrational choice of words and action, Ananse produces a plurality of meaning whose impact reflects not only his mastery of indirection, but also delivers deep, effective, powerful and nuanced communication. In the second oral tale, "How It Is the Elders Say We Should not Repeat Sleeping-Mat Confidences," Ananse employs a unique form of indirection with deeply psychological implications: autoerotic speech-acts. When he points to his own hands and loins and says, he weeds for the love of "a beautiful girl whose arm is like this" and "whose thigh is like this," Ananse pretends to be describing the girl's slender hands and attractive thighs, but, in fact, he is relieving himself of the discomforts of the itching caused by the nettles.

On the psychological level, however, Ananse's speech-act projects Ananse as performing an unconscious erotic act on himself. Freud defines the autoerotic act as a sexual gratification obtained from stimulating one's own body (2004, p. 11). Though, Ananse's ploy is intended to merely obtain some relief from the itching, it also projects Ananse's unconscious mind: his psychosexual desire for the body of the king's daughter. Unconsciously, 
Ananse sees his own body merely as a surrogate for the body of the king's daughter. He constructs a psychological diffusion between his own body and the woman's, so that his autoerotic act should be read as a sexual indirection influenced by his fixation on the woman for whose body he toils to acquire.

We shall look at Ananse's indirection in another oral tale. In "How Ananse Got Aso in Marriage,” Ananse's adopted name, 'Sore-ko-di-Aso' ['Rise-up-and-make-love-to-Aso'] - is decidedly ambiguous. In one sense, the name makes a very offensive proposition; in another sense, it is the name of Nyankopon's emissary, a sacred being. In the tale, it is Nyankopon who sanctions Ananse's seduction of Aso. The strange coincidence of profanity and divinity in the name makes interpretation of the name impossible. The couple, Akwasi and Aso, are unable to decode the real message and intention behind the name, and thus fall victim to Ananse's verbal trap. The fact is that the name is a carefully-crafted double entendre, a clever diffusion of sexuality and sacrality, which enables Ananse to lure Aso into a sexual relationship without resistance from the woman. A closer examination of 'Sore-ko-di-Aso' reveals that the name encodes a plurality of semantic possibilities that conduce to Ananse's sexual aims. In the Akan language, the verb, 'So', means, 'to taste'. For instance, 'M'aso' means 'I have tasted it." Thus, the name, Aso, translates loosely as 'it has been tasted', which generates semantic associations such as 'tasty woman', 'sweet woman', 'she who has been tasted' - connotations that immediately resonate with Ananse's depraved imagination. The verb, 'so', again means 'to spark a light'. This second meaning of the verb produces 'fire' as a sexual symbol. In the context, the name, 'Aso', might be taken to mean 'hot woman', 'woman on heat', 'woman burning with desire'. The polysemic manipulation of the verb 'so' therefore produces meanings ranging from the food metaphor to the fire metaphor.

The food symbol inscribes woman as provider of both culinary and sexual libido for man; the fire symbol sees woman represented as the warmer of man's bed, and by extension, the provider of the life-sustaining heat. The warm bed analogy is a representation of the warm womb. All the above connotations of the verb, 'so', reinforce and composite themselves into a semantic compound to project the trickster's unique vision of woman. Ananse's attitude to language in the Aso episode is another classic example of linguistic 'gamesmanship'. He exploits 'the secret life of words, etymologies true and false, onomatopoeias and tropes of all descriptions' 
(Lercecle, 1990, p. 57) in pursuit of an illicit liaison with a woman who is already married.

In the same tale, Ananse executes even more complex forms of indirection based on metonymic representation. For instance, Ananse does not only ask Aso to pound fufuo, he also asks her to 'Come get meat' insisting that '[I]f you had a pot big enough, I would give you enough meat...' (Rattray, 135). In our view, the act of asking Aso to pound fufuo is an implicit negotiation for sex; we recognise in fufuo-pounding a metaphor for the sexual act, where the pestle, a phallic symbol, thrusts into a mortar representing the pudenda. Still in the tale, 'meat' may be a metonymic representation of the phallus while 'big pot' may assume pudendic significance. Thus, the utterances: 'Come get meat' and '[I]f you had a pot big enough, I would give you enough meat' read as a veiled request for sexual relations. The paradigmatic schematisation and interpenetration of the sexual symbols in the tale can be formulated as follows:

Schema 1: Structural level of symbolism:

Phallic symbol + Pudendic symbol $=$ Coitus

Schema 2: Social level of symbolism

$$
\begin{aligned}
& \text { Ananse }+ \text { Aso }=\text { Coitus } \\
& \text { Pestle }+ \text { Mortar }=\text { Coitus } \\
& \text { Meat }+ \text { Pot }=\text { Coitus }
\end{aligned}
$$

From the schemata above, the denotative meaning of the nouns in the tale (Schema 2) are conditioned by Ananse's libidinal vision (Schema 1) to assume the meaning of sexuality. In other words, Schema 1 provides the symbolic and structural bases for the interpretation of Schema 2, which represents the 'events' and 'existents' (Chatman, 1978, p. 96) in the social domain of the tale. Ananse selects the appropriate culinary motifs and combines them to represent his unique vision of sex. The subtle conceptualisation of sex is an instance of indirection: the trickster bargains for sex with a married woman in the full presence of her husband without exposing himself or attracting censure. In another example of rhetorical deftness in the same tale, the homestead of Akwasi and Aso is transformed into a pornodramatic proscenium the moment Ananse steps into the couple's compound with his basket of meat. One of Ananse's first acts on entering the couple's house is to drop a piece of meat on the floor. We have already identified "meat" as a metonym for the phallus. When Aso draws Ananse's attention to the dropped piece of meat, he says, 'Oh if you happen to have a dog let him go and take it' (Rattray, p. 135). Aso takes the meat and 
gives it to her husband, Akwasi.

In our view, the act of dropping the piece of meat is a deliberate dramatisation of the perceived contamination and rejection of Akwasi's phallus. It is an intentional act devised to inscribe Akwasi's impotence. Having Aso apportion the rejected meat to Akwasi reflects Aso's rejection of Akwasi's 'contaminated' and dysfunctional phallus. In this regard, Ananse's reference to the dog of the house is an indirection for Akwasi. That Aso gives the contaminated meat to Akwasi implies, again, that she, like the trickster, sees her impotent husband as the dog of the house. This seeming complicity of Aso in degrading her husband might explain why she does not mount any resistance when Ananse approaches her for the illicit liaison. In the tale, Akwasi calls Ananse to open the door so that he can go out. Ananse's pseudonym, 'Sore-ko-di-Aso', means ['Rise-up-and-make-love-to-Aso']. On hearing his name, the trickster goes to the woman to demand sex. He asks her: 'Aso, w'ate dee wo kunu kaye?...Osee me nsore mmedi wo' (Rattray, p. 136) meaning 'Aso, did you...hear what your husband said?... He said I must rise up and make love to you' (p. 137). Aso's response to the proposition betrays her complicity. She says: 'Wo mmoa' (p. 136), literally, 'You don't lie (p. 137). Though Ananse's trick is executed through a combination of verbal and psychological ploys, Aso's response demonstrates her willingness to be tricked. Her ready acquiescence is quite strange, though, for an Akan woman in the traditional context which upholds very high moral codes.

\section{Ananse's sexuality and indirection in the written folktales}

The literary writers whose work is shaped by the material and logic of the Akan oral folktale tradition maintain not only the trickster's linguistic deftness in the written text, but, also, his libidinal facility, as happens in the original tradition. We examine two written texts in this section: Yaw Asare's Ananse in the Land of Idiots and Efua Sutherland's The Marriage of Anansewa. In Asare's drama, Ananse invites Princess Sodziisa and her friends to his 'craft shop' to have the princess's measurement taken for a Kente cloth he intends to weave for her. He also wants the girls to: 'Come sing and dance, so the melodies of your voices and the contours of your bodies will smoothen the passage of my needle as I weave.' He provides a reason for inviting the girls: '[The singing] is ...a part of my creative formula. The delicacy of the motifs and designs [of the Kente], the balanced 
blending of the hues [,] will be determined by the dancing and melodious singing of these pretty maidens. It is a matter of artistic expediency....' $\left(1^{\text {st }}\right.$ Movement). What King Dosey and Elder, his chief courtier, do not realise is the indirection involved in Ananse's discourse. It does not occur to them that they are inadvertently engaged in a negotiation with Ananse over the princess's sexuality. While the king's court understands the phrase, "delicacy of the motifs and designs," merely in textile terms, the trickster uses the jargon in sexual terms. In the context, the 'motif' represents the primary libidinal idea, the notion to woo the girl; the 'design' implies the execution of the idea; and 'delicacy,' the weakness and hazards inherent in the idea. Thus, by the phrase, 'delicacy of the motifs and designs,' the trickster plainly concedes to the dangers involved in his plans to seduce the King's danger. Significantly, he says this directly to the king and his courtiers, yet none of them is able to decipher Ananse's coded language. Similarly, the phrase, 'craft shop,' means much more than the place where Ananse sets up his loom to weave; it implies the phallic space, the libidinal context where he intends to deflower the innocent princess.

In the same vein, the sentence, 'Come sing and dance, so the melodies of your voices and the contours of your bodies will smoothen the passage of my needle as I weave,' can be understood as a double utterance. If ordinarily, 'Language...is a...double-voiced...construct whose signifiers are constantly redefined in social and historical contexts' (Benhayoun, 2006, p. 94), Ananse's language is deliberately devised to achieve the double voice, what Mikhail Bakhtin calls a hybrid discourse (1981, p. 304). Thus, in another sense, '[the singing] voices' in Ananse's utterance implies the orgiastic cry in the girls' innocent song: 'Aya...aya...aya!'( $2^{\text {nd }}$ Movement $)$. Similarly, the phrase, 'the passage of my needle,' and the noun, 'bodies,' are closely connected in the context. 'Needle' becomes the phallic symbolic; its incessant thrusting into the body of the cloth that is being woven represents the exploitation of the princess's body. Neither the king nor princess is able to decode Ananse's indirection so that when Ananse asks the princess to 'pose in your favourite position as I ...take [your] measurements,' she understands it only on the literal level. She therefore falls victim to the trickster's seduction. In Sutherland's The Marriage of Anansewa, Ananse's appellation to each of the four chiefs is a brilliant indirection. On the surface, the utterances seem extol the chiefs' political greatness, as is the norm in the Akan tradition, but on a deeper semantic level the symbols evoked project the phallic powers of the chiefs. Chief of Sapa, for instance, is described as: 
'Mighty-Tree/Rooted in the shrine of deity.' The metaphors lend themselves to the following interpretations:

- $\quad$ 'Mighty-Tree' = potent phallus;

- $\quad$ 'Root' = penetration = insemination;

- $\quad$ 'Deity' = The Akan Mother Earth as a deity (Asaase Efua $)=$ Anansewa;

- $\quad$ 'Shrine = womb of Mother Earth = Anansewa's womb.

From the above, the ithyphallic image of the chief and deified sexuality of Anansewa are indirectly presented. The trickster employs the guises of the nsabran - Akan court poetry - tradition and Akan cosmology to inscribe his rhetoric of the erotic. It is a verbal ploy intended to boast the ego of the chief and inscribe the quintessential value of Anansewa. In the letter to the chief, Ananse writes: 'Since forwardness has never been one of my faults, I will not even dare to drop a hint that the way is open for you now to begin oiling the wheels of custom' (Act 1, my emphasis). The utterance above should be understood as a veiled eliciting of gifts from the chief. The gifts are intended to represent the chief's goodwill towards the marriage, and to convince Ananse to approve the marriage proposal. By being indirect about asking for the gifts, Ananse protects his 'face' (Yankah, 1995, p. 11) from the embarrassing phenomenon of financial solicitation. But lying beneath the surface of the utterance is a sexual image which reinforces the 'Tree and Shrine' symbol. '[T] he way is open' is a reference to the chief's accessibility to 'the shrine of deity,' or the womb of Anansewa. In other words, Anansewa's 'shrine'/womb is ready to receive the 'Tree'/chief. '[O]iling the wheels of custom' completes the sense of insemination, where 'oil' symbolises the chief's semen. The 'wheels of custom' that need to be 'oiled' obviously refers to autochthonous elements, therefore, they point to the legs, and by extension, the loins of Anansewa. The utterance is another classic example of pornogrammar. The second appellation, addressed to Togbe Klu, also boasts the phallic tree imagery. Togbe Klu is referred to as: 'Prickly-pear/Cactus.' We recognise in the image two types of cactus joined together: the 'prick cactus' and 'pear cactus', symbolising the male genitalia. The attributes given to the 'prickly-pear cactus' reinforces its sexual representation. Eulogising the cactus, Ananse says: 'Thanks to your prickles/The enemy bleeds,/Thanks to your capacious leaves/Those whom you love/Will always find within them/Water to refresh them' (Act 1). The linkage between the cactus and liquids is very suggestive. 'Blood' represents virginal blood, and 'water,' semen. Again, 'blood' and 'water' represent the 
'pain/pleasure' dyad that is associated with sex. By these sexual symbols, Ananse projects the second chief also as ithyphallic, and proclaims his hallucinating procreative powers. The appellation for Chief of the Mines, the third chief, is rendered as rhetorical questions:

You are coming again, / Aren't you? / You are coming again? Oh where shall wesit... / When driver ants / Are astir / All over our ground?

The furtive sexuality of the panegyric is impressive. Though the phallic object is not explicitly mentioned, virility is implied in the word, 'come,' a euphemism for orgasm and semen. In the context, the repeated 'comings' dramatise the unbridled libido and overwhelming fertility of the Chief of the Mines. In the same sense, the multitude of 'driver ants' is a metaphor for increased sperm count or 'polyzoospermia'. In polyzoospermic situations, a millilitre of semen contains between 350 million and 650 million spermatozoa (Jequier, 2011, p. 46) reflecting the multitude of driver ants. The resemblance between swarms of swimming spermatozoa and an army of driver ants is consistent with our reading of Ananse's symbols. Also consistent with the Akan notion of fertility is Ananse's repeated evocation of autochthony. 'Our ground,' in the utterance, 'driver ants/Are astir/All over our ground,' resonates with Anansewa's womb which is invaded by the multitudinous spermatozoa of the chief. As an instance of rhetorical indirection, the appellation veils the trickster's confidence in the chief's virility, and his own desire for a large family for Anansewa. Clearly, Ananse envisions Anansewa also as extremely fecund. The vision Ananse projects in this appellation coincides with his own procreative over-enthusiasm in 'We Are All Ananse's Children.' In this sense, he casts Anansewa in the mould of Ananse's own primordial wife, Araba Ansaba, whom he impregnates every day, and with whom he populates the world.The appellation to the last royalty, Chief-Who-Is-Chief, opens thus:

Oh Fire-extinguisher/You have caused flame flashes to darken.../BlazingColumn-Of-Fire-Who-Says-I-Will-Not-Be-Halted/Has come to a full stop.../Masculine-One-Destined-To-Contend-To-Victory!/You consume fire... (Act 1).

The image of a 'fire-extinguisher,' a cylindrical metallic tube spewing whitish substance is classically phallic. In the context, the 'blazing fire' that should be extinguished is the burning feminine sexual desire. The evocation of fire as a symbol for feminine sexuality, again, recalls 'Aso', the sparkling fire of Ananse's wife. Such a reading consolidates the image of the whitish emission of the fire-extinguisher as semen. Thus, 'You consume fire' 
refers to the 'Masculine-One's conquest of female sexuality, the dousing of Anansewa's desire by inseminating her body.

\section{Ananse's verbal artistry and psychosexual fixation}

A review of all the tropes employed by Ananse in the oral and written tales examined provides a reading which projects the trickster's mastery of indirection and, also, his phallocentricity. Table 1 and Table 2 below provide the taxonomy of phallic and pudendic imagery used by Ananse in the respective tales. The schemata derived from the trickster's nuanced expressiveness represent what Barthes calls 'dissertation' or 'philosophizing' (1989, p. 27); it is the desperate search for the appropriate language to express the inexpressible - a taboo desire - without attracting censure. In the Akan tradition, speaking in the royal context is a burden, even for the most eloquent speaker, because of the many linguistic protocols involved (Yankah, 1995). When a speaker succeeds in selecting the appropriate vocabulary to deliver a delicate message, he or she is often hailed: 'W'anohuom', literally, 'your mouth smells sweet' indicating the speaker's linguistic competence. Ananse employs the art of royal oratory to veil his sexual overtures to the chiefs. The metaphors he uses to represent the delicate subject of the chiefs' sexuality are seen in Table 1 and Table 2 below.

Table 1: Phallic imagery

\begin{tabular}{|l|l|l|l|}
\hline TALE & TYPE OF TALE & OBJECTS & SYMBOL \\
\hline $\begin{array}{l}\text { We Are All Ananse's } \\
\text { Children }\end{array}$ & Oral & $\begin{array}{l}\text { A gong } \\
\text { A flood }\end{array}$ & $\begin{array}{l}\text { Phallus Semen } \\
\text { (Phallus) }\end{array}$ \\
\hline $\begin{array}{l}\text { How Ananse Got } \\
\text { Aso in Marriage }\end{array}$ & Oral & $\begin{array}{l}\text { Meat (hind-quarters) } \\
\text { Pestle }\end{array}$ & $\begin{array}{l}\text { Phallus } \\
\text { Phallus }\end{array}$ \\
\hline $\begin{array}{l}\text { The Marriage of } \\
\text { Anansewa }\end{array}$ & Written & $\begin{array}{l}\text { Oil } \\
\text { Tree } \\
\text { Erect + Pear Cactus } \\
\text { Driver ants } \\
\text { Fire-extinguisher } \\
\text { Whitish content of } \\
\text { fire-extinguisher }\end{array}$ & $\begin{array}{l}\text { Semen (Phallus) } \\
\text { Phallus } \\
\text { Phallus + Testicles } \\
\text { Sperm (Phallus) } \\
\text { Phallus }\end{array}$ \\
Semen (Phallus)
\end{tabular}


Amissah-Arthur, J.B./Legon Journal of the Humanities Vol. 30.1 (2019)

Table 2: Pudendic imagery

\begin{tabular}{|l|l|l|l|}
\hline TALE & $\begin{array}{l}\text { TYPE OF } \\
\text { TALE }\end{array}$ & OBJECT & SYMBOL \\
\hline $\begin{array}{l}\text { We Are All An- } \\
\text { anse's Children }\end{array}$ & Oral & Female breasts & Womb surrogate \\
\hline $\begin{array}{l}\text { Sleeping-Mat Con- } \\
\text { fidences }\end{array}$ & Oral & Female thighs/loins & Womb \\
\hline $\begin{array}{l}\text { How Ananse Got } \\
\text { Aso in Marriage }\end{array}$ & Oral & $\begin{array}{l}\text { Mortar } \\
\text { Pot }\end{array}$ & $\begin{array}{l}\text { Womb } \\
\text { Womb }\end{array}$ \\
\hline $\begin{array}{l}\text { The Marriage of } \\
\text { Anansewa }\end{array}$ & Written & $\begin{array}{l}\text { Shrine of deity } \\
\text { Wheel (female loins) } \\
\text { Soil - where the Mighty } \\
\text { Tree \& Prickly Pear Cactus } \\
\text { grow } \\
\text { Ground - where driver } \\
\text { ants are astir } \\
\text { Ground - where the } \\
\text { Blazing-Column-Of-Fire is } \\
\text { planted }\end{array}$ & $\begin{array}{l}\text { Autochthonous womb } \\
\text { Autochthonous womb }\end{array}$ \\
Automb \\
Autochthonous womb
\end{tabular}

The trickster's masterly handling and schematisation of erotic images as seen in the taxonomy reflect his deep-seated phallocentricity and psychosexual fixation. To reinforce our view of Ananse's sex-saturated psychology, we provide a brief anatomisation of the trickster. In 'We Are All Ananse's Children,' the trickster defeats Pataku by 'demonstrating' the sheer power and size of his phallus. In 'How Contradiction Came among the Tribe,' we learn that Ananse's phallus is longer than seventy-seven poles hooked together. In the tale, Ananse has an okra farm whose trees are so high that he is unable to harvest the okras even with seventy-seven poles joined together. Curiously, when 'I lie on my back ... [I] am able to use my penis to pluck' the okras (Rattray, p. 107). In the same tale, he accidentally breaks his phallus into seven pieces. It takes a blacksmith two full working days to fit the broken pieces together (p. 109). In another tale, 'How It Came That Many Diseases Came among the Tribe,' Ananse goes to a village 'where there [is] not a single male; all [a]re women. [He] marrie[s] them all' (Rattray, p. 77). Clearly, the trickster's thoughts are dominated by the part of his anatomy that seems inexplicably disproportionate to the size of his entire body. His anomalous phallus seems to dictate his thought patterns.

Ananse has received a lot of negative criticism for his sexual fixations. Ruth Finnegan, for instance, suggests Ananse represents traits people fear (1976, p. 352); Robin Horton is emphatic Ananse is a "psychopath...[who poses] a universal threat to fabric of the community" (1967, p. 237). Ruth 
Minott Egglestone believes the trickster should "never...be taken seriously as a legitimate point of reference for establishing social values" (2001, p. 8). We find the above views a misrepresentation of the essence of the trickster. Finnegan and like-minded critics seem to miss the ambivalent cultural role of the trickster. We attempt to provide a hermeneutic defence of Ananse's seemingly unbridled sexuality from the perspectives of psychology and Akan cosmology.

First, we suggest that Ananse's phallocentricity represents the primal mind in its search for libido - libido in the present sense being the human desire for nutrition, growth, fulfilment and pleasure. According to Carl Gustav Jung (1916, p. 148-49), this generic sense of libido, starting from childhood, defines human development, and reaches its acme in the sexual, procreative function. The search for libido is, therefore, a natural and normal human phenomenon. Ananse's role as the archetypal mind means that he dramatizes innate human desires, his anomalous phallus representing longrepressed impulses hidden in the psyche of every human. He merely projects the inner life of humans outwardly so that people can identify and laugh at their own primitivity. It follows, therefore, that Ananse's sexual fixations do not emanate from a warped psychology; he is neither a psychopath nor a threat to the fabric of society, but merely a mirror of the repressed psychology of humans.

Second, we contend that Ananse's inflated sexual ego is merely a metaphor for the cosmic phallus, the principle underlying all creation in the universe. Jung provides a useful insight in this direction. In his words, '[W]hen I speak of libido, I associate with it the genetic conception which contains not only the immediate sexual but also an amount of desexualized primal libido' (1916, p. 151), which is channelled into higher forms of social and cultural reality (1916, p. 150). Following Jung, therefore, we conceptualise Ananse's sexuality not only in terms of the mundane procreative activity, but also, in terms of the desexualised creative function or 'sublimation' (Jung, p. 150); for instance, the creation of cultural and social phenomena for human use. Our contention is that all these creative processes are possible only through the transformation of the procreative libido into a sublime desexualised form of the impulse. The ithyphallic representation of Ananse must therefore be understood in the dual sense: sexual/desexual, mundane/sublime. Both senses are crucial for the creation of the world and survival of the human race in the Akan worldview. 


\section{Conclusion}

Summarising, we have attempted to theorise Ananse's sexuality in relation to his language. In the process, we have made significant discoveries regarding Ananse's verbal artistry. First, we have come to recognise that Ananse commands a pornogrammar; that is, he boasts a substantial rhetoric of the erotic, which is carefully systematised by the principles of combination and differentiation, and with subtlety and finesse, to construct veiled, indirect meaning. We notice, for instance, that in spite of its wideranging imagery and expressiveness, Ananse's sexual rhetoric is structured around two key images: the ithyphallus and pudenda. The various images Ananse conjures to project his hallucinating sexuality are compounded and formulated as follows:

Pot 1: /gong, fire-extinguisher, needle, knife/ = /+erect, +metallic, +strong, +hard/

Pot 2:/tree, cactus, pestle/ = / +erect, +wooden, +strong, +hard/

Pot 3:/meat, driver-ants/ = /+flesh, +soft/

Pot 4:/sea, oil, foam/ = /+ liquid, +soft/

From the scheme of four pots above, the structured, programmatic eloquence of Ananse becomes evident. He uses a comprehensive range of synonymously- and antonymously-related items, individually, and in combination, to canonise his phallus. Each of the four pots represents a semantic crucible in which disparate phallic symbols can be composited into a semantic/phallic compound. In Pot 1, the common semantic and phallic features are: /+erect, +metallic, +strong, +hard/, projecting the image of virility. Pot 2 produces: /+erect, +wooden, +strong, +hard/ as the common semantic and phallic features, re-inscribing the motif of potency. Pot 3 projects: /+flesh, +soft/ as the common features, while Pot 4 suggests /+liquid, +soft/, both pots emphasising gentility. The data above represents a linguistic system operating on the paradigmatic and syntagmatic principles to produce meaning. For instance, the elements of each of the four pots are paradigms; they can replace themselves through vertical substitution. On the other hand, the same elements lend themselves to the principle of contiguity to create semantic compounds, as we have just demonstrated. Here, they abide by the syntagmatic mechanism. These two linguistic principles justify Ananse's sexual rhetoric as a (porno)grammar. 
Second, we detect from the data that Ananse's rhetoric is not merely erotic; it is also emotional. His use of some many different images in reference to his organ signals an automated discourse: an unrelenting, almost frantic search for an expression to capture his elusive feeling about his phallus. It is this linguistic phenomenon - the battle with language for the most appropriate expression for his indirection - that constitutes his dissertation, harangue or philosophising. Emotional rhetoric is, therefore, an integral part of Ananse's pornogrammar. It is what produces the variability of the imagery and complexity of his discourse.

Third, a closer look at Pot 1, Pot 2, Pot 3 and Pot 4 reveals another remarkable feature of Ananse's discourse: homological ideation or antithetical pairing. From the data, Pot 1 and Pot 2 represent a compound with the common semantic and phallic feature: /+hard/ while Pot 3 and Pot 4 share the common feature:/+soft/. What this means is that Pot 1 and Pot 2 are synonymously-related, like-wise Pot 3 and Pot 4. However, the combined Pot 1/Pot 2 are antonymously-related to the combined Pot $3 /$ Pot 4 producing a homological ordering of language. The antithetical pairing reflects Ananse's complex imagination and conceptualisation of his own phallus. If the grammatical system of the semantic compounding is achieved by the principles of substitution and combination, that of the homological system is realised by the principle of differentiation. What is intriguing about Ananse's grammar is that even the dialectical aspects of his discourse, for instance, the antithetical pairing - Pot1/Pot2 and Pot 3/ Pot 4 - are ultimately diffusive. This is because the homology represents the two dynamic parts of the same single phenomenon: Ananse's phallus. This complex schematisation of images is a reflection of the complexity of Ananse's sexual rhetoric.

Finally, we discover that though Ananse's pudendic representation does not quite match the intense expressiveness that characterise his phallic dissertation, he still demonstrates prolific imagination with regard to female sexuality. Here, the images he employs constitute two semantic crucibles:

Pot 1: /mortar, pot $/=/$ + food, + receptacle/

Pot 2: /shrine, soil, ground/ = /+ autochthonous, + fertile/

From the data above, Ananse conceptualises the pudenda in agricultural terms. For instance, he projects the agrarian progression from 'autochthony' to 'fertility' to 'food' and to 'consumption' (which is the sense inherent in 'receptacle'). The agricultural metaphor and characterisation 
of female sexuality as a life-giving/life-sustaining phenomenon represent a mature indirection for discussing a subject which is normally regarded by the Akan as a taboo.

We have attempted to establish that Ananse produces a pornogrammar. We have tried to discuss the inner mechanisms - the rules of substitution and combination, categories of differentiation and finer details of language use - that justify Ananse's language as a grammar of the erotic. We have argued that Ananse's discourse represents a cultivated and acceptable way of speaking in the Akan traditional context which puts a high premium on decorous speech. The present study, which is, perhaps, the first to investigate the subject of Ananse's sexual innuendos through a systematic, structural approach, seeks to make a substantial contribution to the vibrant fields of linguistics, folklore studies, interrelation of folklore and literature, and Ananse studies in general. 


\section{References}

Asare, Yaw (2006).Ananse in the Land of Idiots. Accra: Study Ghana Foundation.

Bakhtin, M. (1981). The Dialogic Imagination. Michael Holquist (Ed.) Caryl Emerson and Michael Holquist (Trans). Austin, US: University of Texas Press.

Barthes, Roland (1989). Sade Fourier Loyola. Trans. Richard Miller. Berkeley, US: University of California Press.

Benhayoun, J.E. (2006). Narrative, Navigation, and Colonialism: A Critical Account of Seventeenth- and Eighteenth-Century English Narratives of Adventure and Captivity. $\quad$ B r u s s e l s , Belgium: P.I.E. Peter Lang.

Cameron, Deborah (2012). Verbal Hygiene. (1 $1^{\text {st }}$ d.). London: Routledge, [1995].

. Verbal Hygiene for Women: Linguistics Misapplied? Applied Linguistics. 15.4 Oxford University Press, 382-98.

Camp, Claudia V. (2000). Wise, Strange and Holy: The Strange Woman and the Making of the Bible. Sheffield, UK: Sheffield Academic Press.

Chatman, S.B. (1978). Story and Discourse: Narrative Structure in Fiction and Film. New York, US: Cornell University Press.

Danquah, J. B. ([1944], 1968). The Akan Doctrine of God: A Fragment of Gold Coast Ethics and Religion. London, UK: Frank Cass \& Company.

Dundes, Alan (1968). Introduction to the Second Edition. In Louis A. Wagner (Ed.), Morphology of the Folktale. Austin, US: University of Texas Press. $\mathrm{x}$-xvii.

- (1971). The Making and Breaking of Friendship as a Structural Frame in African Folk Tale. In Pierre Miranda and Elli Kongas Miranda (Eds.), Structural Analysis of Oral Tradition ( p p . $171-18$ o ) . Philadelphia, US: University of Pennsylvania Press.

Egglestone, R. M. (2001). A Philosophy of Survival: Anancyism in Jamaican Pantomime. In Sandra Courtman (Ed.), The Society for Caribbean Studies Annual Conference Papers. Retrieved from http://www. scsoonline.freeserve.co.uk/olvol2.html

Fanon, Frantz (1967). Black Skins, White Masks. Trans. Charles Lam Markmann. New York, US: Grove Press. 
Finnegan, Ruth (1976). Oral Literature in Africa. Nairobi, Kenya: Oxford University Press.

Frappier-Manzur, Lucienne (1996). Writing the Orgy: Power and Parody in Sade. Trans. Gillian C. Gill. Philadelphia, US: University of Pennsylvania Press.

Freud, Sigmund (2004). The Wisdom of Sigmund Freud. Bhopal, India: Manjul.

Haring, Lee (1972). A Characteristic African Folktale Pattern. In Richard M. Dorson (Ed.), African Folklore (pp. 165-82). New York, US: Doubleday.

Horton, R. "Ikaki - The Tortoise Masquerade." Nigeria Magazine 94. Sept., 1967. 226-39.

Jequier, A. M. (Ed.). (2011). Male Infertility: A Clinical Guide. Cambridge, UK: Cambridge University Press. (Original work published 2000)

Jung, C.G. (1916).Psychology of the Unconscious: A Study of the Transformations and Symbolisms of the Libido: A Contribution to the History of the Evolution of Thought (Beatrice M. Hinkle, Trans.). New York, US: Moffatt, Yard and Co.

Lercecle, J. J. (1990). The Violence of Language. London, UK: Routledge. Rattray, R.S. (1930). "How Ananse Got Aso in Marriage.” In R.S. Rattray (Ed.) Akan-Ashanti Folktales (pp. 133-137). Oxford, UK: Oxford University Press.

"How Toothache and Birds Came into the Tribe." In R.S. Rattray (Ed.) Akan-Ashanti Folktales (pp. 178-82). Oxford, UK: Oxford University Press.

. "How It Came About That Many Diseases Came among the Tribe." In R.S. Rattray (Ed.) Akan-Ashanti Folktales (pp. 77-81). Oxford, UK: Oxford University Press

"Why It Is The Elders Say We Should Not Repeat Sleeping-Mat Confidences." In R.S. Rattray (Ed.) Akan-Ashanti Folktales (pp. 129-133). Oxford, UK: Oxford University Press

Sutherland, Efua T. (1999).The Marriage of Anansewa. Accra, Ghana: Sedco Publishing Ltd.

Wang, D.W.D (1990). Radical Laughter in Lao She and His Taiwanese Successors. In Howard Goldblatt (Ed.), Worlds Apart: Recent Chinese Writing and Its Audiences (pp. 44 - 63). Armonk, US: M.E. Sharpe. 
Yankah, Kwesi (1995). Speaking for the Chief: Okyeame and the Politics of Akan Royal Oratory. Bloomington, US: Indiana University Press. (1991). "Oratory in Akan Society." Discourse and Society, Vol. 2, No. 1, pp. 47-64. Retrieved from https://www.jstor.org/stable/42884256 